\title{
Why don't U.S. issuers demand European fees for IPOs?
}

\author{
Mark Abrahamson, Tim Jenkinson and Howard Jones ${ }^{1}$
}

\begin{abstract}
We compare the fees charged by investment banks for conducting IPOs in the U.S. and Europe. In recent years the "7\% solution", as documented by Chen and Ritter (2000), has become even more prevalent in the U.S., and is now the norm for IPOs raising up to $\$ 250 \mathrm{~m}$. The same banks dominate both markets but European IPO fees are roughly three percent lower, are much more variable, and have been falling. We review explanations for the gap in spreads and find the evidence consistent with strategic pricing. U.S. issuers could have saved over $\$ 1$ bn a year by paying European fees.
\end{abstract}

Keywords: IPOs, investment banks, fees, underpricing, bookbuilding

December 2010

\footnotetext{
${ }^{1}$ All authors are at the Said Business School, Oxford University. Comments welcome. Corresponding author: Tim Jenkinson, e: tim.jenkinson@sbs.ox.ac.uk, t: +441865 288916. We thank the Centre for Corporate Reputation for financial support.
} 
Ten years ago, Chen and Ritter (2000) documented that IPO issuers in the United States almost always pay a gross spread of exactly seven percent of proceeds to the underwriting syndicate for IPOs of between $\$ 20 \mathrm{~m}$ and $\$ 80 \mathrm{~m}$. This evidence on the clustering of fees prompted an investigation by the Department of Justice, although this was ultimately dropped for a lack of evidence of explicit collusion. A class-action anti-trust lawsuit was also launched, and was settled privately after a 2007 appeals court decision allowing the claim against the underwriters to proceed. ${ }^{2}$ Chen and Ritter had cautioned that explicit collusion was unlikely, but concluded that the clustering of fees is consistent with implicit collusion - or "strategic pricing" - on the part of investment bankers. Subsequent papers by Hansen (2001) and Torstila (2003) argued against even implicit collusion. Hansen maintained that the US IPO market was not unduly concentrated and that barriers to entry were low. Torstila pointed to the clustering of IPO fees outside the U.S. at lower levels, to show that clustering need not be collusive.

The first contribution of this paper is to assess whether the " $7 \%$ solution" still stands in U.S. IPOs. In other cases where clustering of spreads has been identified by researchers, behavior has quickly changed. The findings of Christie and Shultz (1994) that NASDAQ market makers systematically avoided setting quotes on the odd eighths were reported in national newspapers on May 25 and 26, 1994. The next day the use of odd eighths increased sharply and effective spreads fell by nearly 50 percent, as detailed in Christie, Harris and Schultz (1994). We address whether the previous academic research, and subsequent investigations, press reporting, and lawsuits, had any noticeable impact on the clustering of IPO fees in the U.S.

Second, we are now able to make comparisons between the U.S. and Europe that, because of diverging offering practices in the two markets, previous studies could not make. The method of conducting IPOs in the U.S. was, for many years, unique. Unlike IPOs elsewhere, U.S.

\footnotetext{
2 The original class-action lawsuit was filed in 2000, alleging fee-fixing by 32 underwriters, over the period 1994-98. Most recently, the case has been pursued by two plaintiffs, one of which bought the right to bring a claim from a company that had conducted an IPO but had then become bankrupt, and the other being a group of creditors of another company that had similarly gone public and then become bankrupt. In 2006 the District Court ruled that these plaintiffs were not qualified to pursue the case. However, this decision was overturned in 2007 by the $2^{\text {nd }}$ U.S. Circuit Court of Appeals (New York); see the case of Cordes \& Company Financial Services Inc. v. A.G. Edwards \& Sons, Inc. 06-2143-cv. The case was then settled privately in respect of the two plaintiffs, although no class was declared.
} 
offerings have for decades been managed using the "bookbuilding" method, whereby investment banks canvass legally non-binding, but serious, indications of interest from institutional investors before pricing and allocating the shares. IPOs in Europe, by contrast, used the less timeconsuming and, in terms of direct costs, cheaper fixed price method or tender/auction process (see, for instance, Jenkinson and Ljungqvist (2001) and Ritter (2003)). This difference was cited by industry participants as the reason why gross spreads were lower in Europe than in the U.S. In recent times, however, all this has changed: Ljungqvist, Jenkinson and Wilhelm (2003) indicated that by the end of their sample period (July 1999), approximately $80 \%$ of all non-U.S. offerings were being bookbuilt (Europe constitutes two thirds of their sample). The trend has continued. For the past decade, with the exception of some very small offerings and periods when certain countries have experimented with auctions, the vast majority of European IPOs have used bookbuilding. Now that European offering techniques have converged with those in the U.S., we can reopen the debate on IPO fees.

In order to make the comparison between U.S. and European IPOs, we have assembled a dataset of European bookbuilt IPOs with spread and underpricing data, both of which are notoriously difficult to source accurately. The last Europe-wide gross spread study can be found in Torstila (2001), but this covers the 1986-1999 period when a multiplicity of offering techniques frustrated any attempt to generalize the results. Our dataset, which covers ten years of data from 1998 to 2007, matches a dataset of U.S. IPOs drawn from the same period using standard sources. Furthermore, with the international integration of capital markets, leading investment banks compete for IPO business on both sides of the Atlantic. We are able to compare how a given bank charges for its (almost identical) services at home and abroad. With accurate IPO data available from these once distinct but now comparable markets, we are able to measure - and shed light on - the disparities between them.

Our main findings are as follows. First, the "7\% solution" has become even more prevalent in the U.S. than when Chen and Ritter (2000) reported. Between 1998 and 2007, 95.4 percent of U.S. IPOs between $\$ 25 \mathrm{~m}$ and $\$ 100 \mathrm{~m}$ had spreads of exactly 7 percent fees. The comparable figure between 1989 and 1998 (as reported by Chen and Ritter, having adjusted their IPO range for inflation) was 84 percent, although signs of increased clustering at 7 percent were evident towards the end of their sample period. Second, the "7\% solution" applied to larger U.S. offerings in 1998-2007 than in the decade before. While Chen and Ritter showed virtually no 
IPOs over $\$ 150 \mathrm{~m}$ with a $7 \%$ spread, we find that 77 percent of all offerings between $\$ 100$ and $\$ 250 \mathrm{~m}$ charge exactly $7 \%$. Third, European IPO spreads do not cluster, and only 1 percent experience fees as high as 7 percent. Within the $\$ 25 \mathrm{~m}-\$ 100 \mathrm{~m}$ range, fees for European IPOs average just over 4\%. Indeed, European IPOs are always cheaper: we find that there is a " $3 \%$ wedge" between European and U.S. IPOs after controlling for size, issue characteristics, syndicate structure and time or country effects. Fourth, whilst spreads are lower for the larger offerings in both regions, our multivariate analysis indicates that fees for the larger U.S. IPOs have tended to increase in our sample period, while European IPOs have been getting cheaper. Finally, we find that the same investment banks charge significantly lower fees for conducting IPOs in Europe than for similar IPOs they underwrite in the U.S.

Some argue that institutional differences between the two markets explain the 3\% wedge. We explore five of these favored explanations: legal costs, retail offerings, litigation risk, sellside analysts, and the possibility that narrower underpricing might offset higher fees. However, we find no evidence that these explanations materially explain the difference in fees. Indeed, regarding the latter issue, we find that European IPOs are underpriced less than U.S. IPOs.

The economic significance of this difference in fees between the U.S. and Europe is considerable. From 1998-2007 the U.S. companies in our sample raised $\$ 412$ billion via IPOs. Our best estimates suggest that had these IPOs been conducted at European fee levels the savings to U.S. issuers over the period would have totaled $\$ 11.4$ billion - or over $\$ 1$ billion per year. ${ }^{3}$

We offer no definitive answer to the question posed in the title. Given that cost, or quality, differences cannot explain the differences in fees charged by the same investment banks for conducting IPOs in the U.S. and Europe, the only remaining explanation is the nature of competition. We conclude that, despite entry into both markets, strategic pricing occurs in the U.S. but not in Europe. The evidence in this paper may help to strengthen the negotiating position of U.S. issuers when awarding future bookrunner mandates.

The remainder of this paper is structured as follows. In the next section we describe the data and the sample summary statistics. Section II analyzes the dataset using a number of univariate sorts and reports multivariate regression results. Section III investigates possible

\footnotetext{
${ }^{3}$ This is based on the 1931 U.S. IPOs in our sample; the actual saving would be larger, as our sample is constructed using standard IPO omissions (investment companies, SPACs, small offerings, etc.).
} 
explanations for the difference in fees between the U.S. and Europe, and Section IV discusses the results and presents conclusions.

\section{Data}

One objective of this paper is to produce the most up-to-date and internationally comparable dataset of IPOs. Previous cross-country studies that analyzed spread disparities have been constrained by the multiplicity of issuing methods; in this paper all the IPOs use the same bookbuilding process. We exclude auctions, fixed price and hybrid offerings. This dataset is therefore the first of its kind and allows a more powerful comparative analysis.

Details of how the dataset is constructed are given in the Data Appendix. The universe of IPOs is drawn from the industry-standard Securities Data Company (SDC) Platinum database, for both U.S. and European offerings. ${ }^{4}$ The period under consideration runs from January 1998 to December 2007. Part of the contribution of this study is to provide an updated analysis of how spreads have evolved in the U.S. in recent years. Chen and Ritter (2000) focused on IPOs where proceeds (excluding over-allotment options) were at least $\$ 20$ million, as measured in 1997 U.S. dollars. ${ }^{5}$ We express all the IPOs in our sample in 2007 U.S. dollars, and the equivalent cut-off then becomes \$25 million. We replicate Chen and Ritter's sample almost exactly for 1998, the overlapping year in our dataset. In addition to the restriction that IPOs are conducted by bookbuilding and raise at least $\$ 25 \mathrm{~m}$, we apply a number of standard exclusions used in the IPO literature: closed-end funds, SPACs, REITs, unit offerings, and offerings where all tranches contain depositary receipts (e.g. ADR or GDR offerings) are all excluded. This produces a base sample of 1943 U.S. IPOs and 1756 European IPOs.

The main variable of interest for this paper is the gross spread. Whilst for U.S. companies such information is readily available from SDC Platinum, obtaining gross spread and pricing data for European offerings is fraught with difficulty: it is not a regulatory requirement in most European countries for the gross spread to be reported in the prospectus (unlike the U.S.). The

\footnotetext{
${ }^{4}$ The nationality of an IPO is determined by the country of the primary exchange where the issue is listed, rather than the location of the business or where it is incorporated. For example, an Israeli company going public on London's main market would be classified as a UK IPO.

${ }^{5}$ The authors argue that IPOs with proceeds less than \$20 million will face significantly higher fees due to diseconomies of scale and that these offerings may also have associated underwriter warrants.
} 
fact that many European prospectuses are not published in English doubtless also contributes to the low coverage in SDC Platinum, which reports gross spreads for only 29\% of European IPOs. We explain in the Data Appendix how we merge information from Dealogic to increase the proportion of European IPOs for which we have gross spread information to 53\%. Share prices are derived from CRSP for the U.S. and Datastream for Europe. After excluding a small number of issues for which we could not obtain pricing information the final sample comprises 1931 U.S. IPOs and 914 European IPOs.

The summary statistics for this sample are presented in the four panels of Table 1. Panel A presents results for the full sample, while Panels B-D separate the results into three ranges according to the IPO proceeds. Panel B covers proceeds from $\$ 25 \mathrm{~m}$ to $\$ 100 \mathrm{~m}$ and is equivalent, in 2007 U.S. dollars, to Chen and Ritter's (2000) \$20m-\$80m range.

The distribution of IPOs over time follows a similar pattern in both the United States and Europe, where 1999 and 2000 (which constitute more than a third of the sample in both markets) clearly show the influence of the bubble period on IPO activity, 2001-2003 the subsequent recession and 2004-2007 the recovery that preceded the credit crunch period. In both markets median proceeds spike in 2001-03 reflecting the trend away from small issuers going public following the collapse of the tech market. Even in the subsequent recovery, however, the median issue size was larger in both regions than in the 1998-2000 period, suggesting a more lasting shift away from smaller issues.

One possible concern is that because the European sample is constrained by the availability of spread data, the dataset could be unrepresentative. Comparing the sample with the full universe of 1756 European IPOs shows that most of the omitted IPOs fall into the $\$ 25 \mathrm{~m}$ $\$ 100 \mathrm{~m}$ category, as one might expect. Nonetheless, within each size category, the median proceeds of the universe are within $10 \%$ of the final European sample median proceeds and we are therefore satisfied that the sample is robust in this respect.

Given that the investment banks running the IPO - the "bookrunners" - capture most of the gross spread awarded to the syndicate, and that banks compete fiercely for this position, we record the names and number of bookrunners for each IPO. Hu and Ritter (2007) note that the number of bookrunners has been increasing in the U.S. in recent years; Table 1 confirms this finding for the U.S. and reports similar trends for Europe. The increased propensity of issuers to employ several bookrunners in the syndicate has been linked to reducing placement risk, 
information production and the effects of increased intra-syndicate competition on the final offer price (see Corwin and Schultz (2005), Davidson, Xie and Xu (2006), Jenkinson and Jones (2009)). In both the U.S. and Europe, "local" bookrunners are dominant, consistently appearing in $80-90 \%$ of the IPOs in their markets. However, in both markets the proportions of "foreign" bookrunners have increased over the time period, although the propensity of European issuers to employ U.S. bookrunners is noticeably greater than the reverse propensity.

This latter observation is given some depth by the statistics presented in Panels B-D: we see that European IPOs very seldom have U.S. bookrunners for small offerings, but that for large offerings, nearly all European IPOs include a U.S. bookrunner. This is perhaps to be expected: small IPOs are often placed in one region, whereas large IPOs are frequently placed globally where the reach of a U.S. underwriter will be attractive. In the case of U.S. IPOs, however, nonU.S. bookrunners are only involved in a minority of offerings, regardless of size.

In the following section we turn to the direct costs to issuers of performing IPOs in the U.S. and Europe; Section III then discusses possible explanations for the discrepancies by considering the indirect cost of underpricing and other potential direct costs.

\section{How do U.S. and European IPO costs to issuers compare?}

Perhaps the most striking feature of Table 1 is the difference in mean gross spread between the U.S. and Europe. Panel A suggests that there is a wedge of some 3 percentage points between U.S. and European spreads, a finding that is surprisingly robust across the sub-samples in Panels B-D. For the largest IPOs, it would appear true to say that European IPOs are "half price" relative to U.S. IPOs. Furthermore, while average U.S. spreads have remained steady around the $6.7 \%$ mark, European spreads have tended to fall, from around 4\% in 1998 to $3.2 \%$ in 2007 .

The spreads for smaller IPOs, for which Chen and Ritter (2000) reported a tight clustering at 7\%, are reported in Panel B. The average spread for the U.S. issuers in this range is $6.98 \%$, with $95.4 \%$ of IPOs reporting a spread of exactly $7 \%$. In Figure 1 we show how this proportion has moved in recent years. Whilst there is a little variation over time, there is no observable trend towards lower spreads in the U.S. In only two years - 2001 and 2006 - did the proportion of 7\% spreads drop below $90 \%$, and in the final year of the sample 68 of the 70 IPOs in this size range had spreads of exactly $7 \%$. There is, therefore, no evidence whatsoever that the " $7 \%$ solution" 
has disappeared in the U.S. with the passage of time. In fact our results suggest the clustering has become even more pronounced. This is particularly surprising given that the volume of IPOs has been historically low in most years since 2001, which might have induced investment banks to compete on spreads to win mandates. The fact that this did not occur is consistent with the implicit collusion dynamic equilibrium game of Rotemberg and Saloner (1986), where the present value of future profits from maintaining high fees is expected to be large relative to the short-term profits from cutting fees to gain market share in cold markets.

In comparison, the average gross spread on European IPOs in Panel B is $4.2 \%$, and for only $1.6 \%$ of the offerings is the gross spread as high as $7 \%$. There is considerable variation in spreads within Europe as can be seen in Figure 2, where European spreads are shown as hollow dots and U.S. spreads are solid. The contrast between the markets is striking and clearly reveals three key differences. First, the sheer dominance of the 7\% pricing in the U.S. is palpable (to get a grasp of the thickness of the 7\% "line", recall that for this price range there are almost three times as many offerings in the U.S. sample than in our European sample). Second, European spreads are never in excess of 7\%, suggesting that the U.S. pricing represents an upper bound on IPO pricing across the Atlantic. Finally, European pricing is not concentrated at any particular level. The range of gross spreads is also considerable with nearly one-third of the offerings having fees of 3.5\% or below. We consider later, in the regression analysis, whether there are any systematic explanations for price variation in Europe, though it is clear that for both markets, economies of scale do not seem to be significant over this range of proceeds.

We also find striking results for larger offerings. In particular, we find that, in the last decade, the $7 \%$ solution has spread to larger IPOs. Panel $\mathrm{C}$ of Table 1 reports that the average gross spread for $\$ 100-500 \mathrm{~m}$ U.S. IPOs is $6.75 \%$. This reflects the fact that a $7 \%$ spread is still observed in $65.2 \%$ of such offerings. This can be seen from Figure 3, which shows the gross spreads for the full samples of U.S. and European IPOs plotted against the natural logarithm of proceeds. The comparable figure from Chen and Ritter (2000, Figure 2, p.1112) exhibited virtually no IPOs larger than $\$ 150 \mathrm{~m}^{6}$ with a $7 \%$ spread. In contrast, in Panel A of our Figure 3, $7 \%$ spreads are frequently observed for issues up to around $\$ 400 \mathrm{~m}\left(\mathrm{e}^{6}\right)$. In searching for the new

\footnotetext{
${ }^{6}$ This is re-valued into 2007 U.S. dollars for easy comparison. The threshold in Chen and Ritter's figure is around $\$ 122 \mathrm{~m}\left(\mathrm{e}^{4.8}\right)$.
} 
threshold where 7\% fees are no longer the norm, a conservative estimate would be $\$ 250 \mathrm{~m}$ : $77 \%$ of IPOs raising between $\$ 100-250 \mathrm{~m}$ charge exactly $7 \%$. This is consistent with a remark made to us by one U.S. investment banker that "we don't break spread below $\$ 250 \mathrm{~m}$ ". This language is telling, and suggests an industry norm consistent with strategic pricing. Indeed, our results show that the $7 \%$ focal point for fees has become both more pervasive for the sub-\$100m IPOs and has spread to larger offerings, in spite of the obvious economies of scale associated with the work of the investment banks.

This is not to say that fees do not eventually reflect the economies of scale. Panel D of Table 1 and Figure 3 clearly demonstrate that fees fall, and become more variable, in both regions as offerings increase in size. In general there is much greater variation in gross spreads in Europe for all sizes of IPO, along with the 3\% wedge we described earlier. For instance, consider the following comparison. The lowest spread we observe among the U.S IPOs is $2.5 \%$, associated with a large $\$ 2.4 \mathrm{bn}$ offering. In contrast, 195 European companies ( $21 \%$ of the sample) had spreads at or below this level, with the smallest raising just $\$ 26 \mathrm{~m}$. As might be expected, both markets show clustering around 0.5 percentage point values: in the U.S. there are clusters at $7 \%$, $6.5 \%$ and $6 \%$, though, as noted above, proceeds need to be considerably larger than in Europe before the non-7\% clusters take effect. In Europe clusters at 3\%, 4\% and 5\% are evident even for the smallest offerings.

These spread discrepancies raise the obvious question: are different banks operating in the U.S. and Europe, and do their different corporate structures account for the price differences? To explore these issues, we list, in Table 2, the top ten bookrunners by proceeds for each market: 8 of the 10 top banks are common to both markets and, although the ranking differs slightly, the top three banks in the U.S. - which are all U.S. banks - are also the top three banks in Europe. ${ }^{7}$ Given the similarities in the leading banks in both markets, the difference in spreads is unlikely to be explained by composition effects: we compare spreads charged by the same banks in different markets and confirm the 3\% wedge. For instance, among the U.S. banks, Goldman Sachs and Morgan Stanley have wedges of $2.95 \%$ and $2.97 \%$ respectively, and the European banks Credit Suisse and Deutsche have wedges of $2.98 \%$ and $3.09 \%$ respectively. Therefore, the lower fees in

\footnotetext{
${ }^{7}$ We explain the classification of banks in the Data Appendix.
} 
Europe cannot be explained by the composition or nationality of the investment banks operating in each market.

Regarding market shares, the U.S. market is more concentrated than Europe. The share of the top three banks in the U.S. is just below 50\% whereas in Europe the share of the top three banks is just under $30 \%$, and the corresponding shares for the top ten banks are $86 \%$ and $67 \%$ respectively. The Herfindahl-Hirschman Indices are 1067 for the U.S and 545 for Europe, neither of which would indicate excessive concentration. However, while the U.S. is clearly one market, Europe is not yet fully integrated, and so measuring market shares on a pan-European basis may ignore pockets of concentration observed in particular countries. Nonetheless, in the vast majority of the larger European deals, regardless of country, U.S. banks compete for - and win bookrunner mandates alongside "national champion" banks, such as Mediobanca and Dresdner who operate almost entirely in one country.

To summarize the evidence to this point, we find that over the last decade the $7 \%$ solution has not only persisted in the U.S. but has spread to larger IPOs. We find the same banks charging approximately 3\% less for similar sized IPOs, using a common issuing technique, in Europe. There is no evidence that this is a U.S. bank effect: European banks operating in the U.S. price in the same way. And, although the U.S. is a more concentrated market, there are clearly many competitors for each mandate and there is little evidence that concentration is excessive.

Having analyzed spreads according to various univariate sorts, we now turn to a multivariate analysis. This allows us to analyze whether spreads have been increasing or decreasing over time, controlling for syndicate structure, and issue characteristics. Table 3 reports the OLS regression results for the following model, which includes dummy variables for high tech $^{8}$ IPOs, venture capital backing, privatizations, and syndicates including multiple bookrunners, ${ }^{9}$ as well as year dummies:

\footnotetext{
${ }^{8}$ We employ the detailed SIC code-specified definition of "tech" as used by Loughran and Ritter (2004).

${ }^{9}$ We make no distinction between the nationality of the bank(s) in the syndicate. We find no significant impact of the mix of U.S. or European banks within the syndicate, which is consistent with our earlier finding that spreads depend on the market rather than the bank nationality.
} 
spread $_{i}=\alpha+\beta_{1} \operatorname{lnProceeds_{i}}+\beta_{2}$ Tech $_{i}+\beta_{3}$ VCbacked $_{i}+\beta_{4}$ Privatisation $_{i}+\beta_{5}$ MultipleBookrunners $_{i}$ $+\left(\sum_{j=1999}^{2007} \beta_{j} \text { Year }_{j}\right)_{i}+\left(\sum_{k} \beta_{k} \text { Country }_{k}\right)_{i}+\varepsilon_{i}$

For the regressions on European data we also include country dummies for the four most prominent European markets (UK, Germany, France and Italy).

We split the samples according to issue size as before. Considering first U.S. IPOs in the $\$ 25 \mathrm{~m}-\$ 100 \mathrm{~m}$ range, none of the explanatory variables, including the time dummies, are significant - with the exception of VC backing, which is associated with marginally higher spreads. This is hardly surprising given the clustering at $7 \%$ we have already documented. The equivalent regression for the European sample reveals variation across European countries - with the UK IPOs being relatively cheap, and German and French IPOs relatively expensive. In neither the U.S. nor Europe are spreads significantly affected by engaging more than one bookrunner.

For the $\$ 100 \mathrm{~m}-\$ 500 \mathrm{~m}$ IPOs we observe that, in both markets, economies of scale are reflected in spreads. There is also evidence that high tech IPOs are associated with marginally higher spreads (as are VC-backed IPOs, although the coefficient is only significant in the U.S.). For these larger IPOs spreads are lower in Europe (but not in the U.S.) when there are multiple bookrunners and the differences between European countries are less pronounced. However, the time dummies reveal the most interesting coefficients: for the U.S. the time dummies suggest spreads have increased significantly - by 15 to 30 basis points - relative to 1998 . This is consistent with our earlier finding that the 7\% solution has been spreading to larger IPOs in the U.S. over the last decade. The opposite result is found in Europe: in the last four years of the sample spreads were significantly lower - by around 50-75 basis points - relative to 1998 .

For the largest IPOs, we find similar results. For the U.S., the time dummies are positive from 2000 onwards, although they lack statistical significance in most years. Multiple bookrunners are associated with slightly lower fees. For Europe the time variation in spreads for the largest IPOs is even more striking: spreads have fallen by around 100 basis points, which is considerable relative to the average spread within this size bracket of just $2.9 \%$ in 1998 . For these larger IPOs we find that engaging multiple bookrunners has no significant impact on spreads. 
The regression analysis therefore contributes some interesting time-series results to the earlier univariate analysis. There has been a significant decline in fees for European IPOs above $\$ 100 \mathrm{~m}$ over the last decade. Recall, from Table 1, that this is the segment of the market where U.S. banks have entered the European market most successfully over the last 10 years. The fragmented market for investment banking services that existed within Europe was favorable for competition, which duly occurred with the continued integration of global markets and the widespread adoption of the similar bookbuilding techniques. U.S. banks have built substantial market share within Europe, but have had to discount their fees heavily. At the same time, the fees U.S. banks charge in their home market have, if anything, increased, and the more modest entry of European banks into U.S. IPOs has not occurred by competing on fees. The difference in spreads between the markets is, therefore, consistent with greater and increasing competition in Europe, and strategic pricing - over an increasing range of IPOs - in the U.S.

However, such comparisons rely on the assumption that the actual services offered, either explicitly or implicitly, are broadly similar, which some academics and practitioners dispute. In the following section we examine five of these alternative explanations - other than the degree of competition - and assess whether they can explain the spread differences we have documented.

\section{What factors could explain the differences in costs?}

Although IPOs techniques have converged, it is possible that the costs incurred by investment banks, and the services they offer, could explain the difference in the spreads we have documented. We categorize these potential explanations into direct and indirect costs. Direct costs may differ due to the treatment of legal expenses, the costs of retail distribution and research analysts, or the extent of litigation risk. Indirect costs relate to underpricing - it is common in the literature to treat the underpricing of IPOs as money left on the table by the issuer. Since investment banks have a significant influence on the offer price, it is possible that narrower underpricing may offset higher spreads. We consider each of these in turn.

\section{A. Legal Expenses}

Legal expenses - in particular helping to produce the prospectus and guiding the issuing company through the IPO process - can be a sizeable cost, and the treatment of these expenses 
differs between the U.S. and Europe. In U.S. IPOs, the underwriters' legal expenses are paid out of the gross spread while in Europe they are largely reimbursed by the issuers or vendor separately from the gross spread. ${ }^{10}$ We need, therefore, to subtract U.S. underwriters' legal costs from U.S. gross spreads to make a like-for-like comparison between markets. We have obtained from industry sources the typical underwriters' legal expenses for U.S. IPOs of various sizes. ${ }^{11}$ These typical expenses are given in Table 4, and are consistent with the estimates of Beatty and Welch (1996, Table 1). Table 4 also shows, for each size category of IPO, the weighted average spreads and the weighted average U.S. spreads adjusted for these legal expenses. These adjustments narrow the gap between U.S. and European gross spreads but explain only a small fraction of the difference.

These figures allow us to estimate the total additional fees that were charged for U.S. IPOs, relative to comparable European offerings, on a like-for-like basis. Over the ten-year period U.S. IPOs raised $\$ 412.3$ billion. At the (adjusted) weighted average fee of $5.45 \%$, this resulted in fees of $\$ 22.5$ billion. Had U.S. issuers been able to demand European fees (weighted average spread of $2.68 \%$ ) this would have saved issuers $\$ 11.4$ billion over the ten-year period.

\section{B. Retail}

It is claimed by U.S. underwriters that the relatively high U.S. gross spreads reflect the high fixed costs of the retail distribution networks of U.S. banks. There are two assumptions behind this claim, which cannot be tested precisely: that U.S. banks' retail networks play a larger role in the distribution of U.S. IPOs than their European counterparts in European IPOs and/or that U.S. retail networks are more costly than those of European banks. However, a number of arguments cast doubt on the link between high U.S. gross spreads and retail distribution networks. First,

${ }^{10}$ We understand from industry sources that, from around 2002, issuers in Europe tended to cap the amount of the underwriters' legal expenses that they will reimburse separately. As a result, underwriters of European IPOs sometimes have to bear part (up to one-half) of their own legal expenses out of the gross spread. To be conservative we have not reflected this in our analysis. Legal expenses incurred by other parties are borne directly by those parties in both markets and do not concern us. Note that we only consider legal expenses connected with the IPO, rather than the cost of any subsequent lawsuits.

${ }^{11}$ It should be noted that, in practice, legal expenses vary widely to reflect factors other than offer size, notably complexity and time to completion. 
retail networks do not exist solely for the distribution of IPOs: they sell secondary equity and fixed income instruments as well as a wide range of other financial products and services. To the extent that (underpriced) IPOs are attractive products for the banks' retail clients, the retail network benefits from its IPO business as well as vice versa. Second, as the costs of retail networks are to some extent fixed, we should expect this effect to raise the gross spread for $\$ 25 \mathrm{~m}$ IPOs above that of $\$ 250 \mathrm{~m}$ IPOs. However, as we have seen, U.S. gross spreads persist stubbornly at $7 \%$ within this range.

Furthermore, if IPOs were paying for retail networks, IPOs that include a retail tranche should command higher gross spreads than others. We have some evidence against this hypothesis: the Dealogic database that we used to supplement the spread data for our European sample has an indicator for whether an IPO contains a retail component. For the 788 European IPOs where we have this data, 399 have a retail tranche. We re-run the regressions in Table 3 on this subset of European IPOs including a dummy to capture whether a retail component is in the offering. The results are presented in the Internet Appendix. Rather than find a positive coefficient on the retail dummy, we a find negative but insignificant estimate on the full sample. ${ }^{12}$ We therefore find no convincing evidence to support the hypothesis that the existence of retail tranches in IPOs either increases, or explains the divergence in, gross spreads.

\section{Litigation Risk}

Industry participants point to greater litigation risk in the U.S. as a reason for higher U.S. gross spreads. This link has received scant attention in the academic literature, which has focused on the link between litigation risk and underpricing. Although even this link has been contested (Alexander (1993), Drake and Vetsuypens (1993)), it has more intuitive appeal than a link between litigation risk and gross spreads. Most U.S. IPO-related lawsuits are brought under Section 11 of the Securities Act 1933, under which buyers in the IPO may sue for damages based on the difference between the offer price and the price at which they sold the shares (or the price at the time of the lawsuit if the shares have not been sold). A lower offer price reduces not only

\footnotetext{
${ }^{12}$ An informal check for the U.S. might be to compare the fees charged by Merrill Lynch and Citigroup, which have the most extensive retail networks. There is no evidence from Table 2 that these banks charge higher fees on average.
} 
the likelihood of a suit but also the damages if the suit is successful, while a higher gross spread does neither. Moreover, a lower offer price spreads the cost of insuring against litigation risk between the issuer/vendor and the underwriters, with the former suffering a reduction in proceeds and the latter suffering a reduction in compensation, which is a fixed percentage of proceeds. A high gross spread would, by contrast, compensate only the underwriters for this risk and would do so at the expense of the issuer/vendor. Since under U.S. law the parties to an IPO are jointly and severally liable for damages (see Lowry and Shu (2002)), the use of the gross spread as litigation insurance would effectively result in one potentially liable party insuring the other.

Even if we did accept that gross spreads were compensation for litigation risk, this would explain only a small part of the difference between the U.S. and Europe. In a sample of 1,841 U.S. IPOs between 1988 and 1995, Lowry and Shu (2002) found that 84 were the subject of Section 11 lawsuits, with a further 22 IPO-related actions being brought under other parts of U.S. securities legislation. The average damages in the 84 Section 11 cases represent $10.1 \%$ of IPO proceeds. Allowing for the larger average size of the IPOs that were subject to lawsuits $(\$ 27 \mathrm{~m}$ against $\$ 21 \mathrm{~m}$ for the rest), the cost of damages spread across all IPOs in their sample represents just $0.58 \%$ of proceeds. Their sample ends in 1995 and therefore does not include the "bubble" period, when a large number of floated companies were the subject of class actions. ${ }^{13}$ As we see in Table 1, average U.S. gross spreads change little when we exclude IPOs from 1999-2000, so if there were greater litigation risk from these transactions, it is barely reflected in spreads. And given that the cases amount to fraud charges rather than negligence, it is unclear whether banks would have priced this risk into their spreads in the first place.

Even on the most conservative assumptions, then, the effect of litigation risk on gross spreads would do little to narrow the gap between the U.S. and Europe. However, as the discussion above indicates, it is unlikely that gross spreads are, in fact, used as insurance against litigation risk at all and that, if any of the cost components is being used, it is underpricing which we investigate below.

\footnotetext{
${ }^{13}$ Stanford's Securities Class Action Clearinghouse reports that there were 312 cases in 2001 related to IPO allocations. There had been no such cases in the years leading up to 2001 and only one such case has subsequently been filed, in 2002. See http://securities.stanford.edu
} 


\section{Analysts}

According to this argument, IPO gross spreads may partially reflect the high cost of research analysts, and that bookrunners with highly-rated analysts may be able to recoup these costs by charging a higher spread. Our objections are similar to those made above on retail networks. First, an analyst's involvement in an IPO may benefit him or her as much as vice versa. Second, the lack of variation in gross spreads for the smaller IPOs shows that the deals where analyst involvement is greater (e.g. for companies which are especially difficult to value) do not command the higher spreads one would expect if analyst costs were an important determinant of U.S. spreads. Third, since the costs of an analyst are fixed, we should expect $\$ 25 \mathrm{~m}$ IPOs to pay higher spreads than $\$ 250 \mathrm{~m}$ IPOs. ${ }^{14}$ However, the assumption behind this claim - that the costs of an analyst for a U.S. IPO are higher than for a European IPO - can be challenged as well. For while in both the U.S. and Europe the underwriters' analysts are expected to provide continuing coverage of the floated company, in Europe it is usual for them to prepare written research before the IPO while in the U.S. this is prohibited (see Jenkinson, Morrison and Wilhelm (2006)). If anything the role of analysts is therefore greater in European IPOs than in U.S. IPOs. Different compensation levels for U.S. and European analysts are unlikely to be a factor either: the IPO business in both markets is, as we have shown, dominated by the same banks.

However, although there are strong grounds to doubt the relevance of analyst coverage in explaining the cost differences we have documented, we use our dataset to explore whether issuers are prepared to pay more for bookrunners with a well regarded analyst. This "analyst lust" hypothesis has been suggested by Loughran and Ritter (2004). To do so we analyzed whether any of the bookrunners had an Institutional Investor (II) All-Star analyst team in the relevant sector. We explain the construction of the All-Star variable in detail in the Data Appendix. We follow the approach of Cliff and Denis (2004): for each IPO the All-Star dummy variable captures whether any bookrunner had an analyst placed first, second or third in the relevant sector in the Institutional Investor (II) All-Star rankings. Like Cliff and Denis (2004, p. 2879), we recategorized some II definitions to match IPO sectors when the sector definitions did not

\footnotetext{
${ }^{14}$ Since the Global Settlement of 2003, analysts' compensation may not be linked to their role in investment banking business so, at least in terms of IPOs, their costs are fixed.
} 
correspond precisely. ${ }^{15}$ Even so, II only provide analyst rankings, in the relevant years, for sectors covering three-quarters of the IPOs. When we re-run the regressions in Table 3 to include the presence of an All-Star analyst among the bookrunners we find, as did Cliff and Dennis, no impact at all on U.S. IPO spreads. For European IPOs up to $\$ 500 \mathrm{~m}$ there is no impact on fees, and for the largest IPOs there is some evidence that fees are higher, although the results are only marginally significant. Full results are available in the Internet Appendix. If the presence of an All-Star analyst explained higher U.S. spreads we should expect U.S. offerings with such an analyst to pay higher spreads than others. We do not find this, and our results do not support the argument that higher U.S. spreads reflect the perceived quality of analysts.

\section{E. Indirect Costs of Underpricing}

A rather different potential explanation for higher U.S. gross spreads is that spreads are only one of the determinants of net proceeds to the issuer, and that they should be seen together with underpricing, which is the other major cost. If we return to Table 1, underpricing is indeed another dimension in which the U.S. and European samples differ considerably. In both regions the "bubble" period of 1999 and 2000 is clear: both markets show a surge in IPO activity along with high average levels of underpricing. However, mean and median underpricing across the whole sample in Europe is approximately half the level of underpricing in the United States, and even when the "bubble" period is removed, both mean and median U.S. underpricing (14\% and $8 \%$ respectively) are considerably higher than in Europe ( $9 \%$ and $5 \%$ respectively). The subsample analysis reveals that the discrepancy is greatest in the $\$ 100 \mathrm{~m}-\$ 500 \mathrm{~m}$ category, with U.S. underpricing outranking European underpricing by a factor of 3 for the period as a whole.

These summary statistics therefore cast doubt on the hypothesis that lower underpricing offsets higher spreads. To extend the analysis we run regressions with underpricing as the dependent variable, and similar controls for issue size, type, and syndicate structure. We introduce the All-Star analyst variable, although since we only have such information on a subset of the IPOs we report this regression separately. We include a dummy variable for Europe that allows us to test whether, allowing for these controls, underpricing differs in the two regions. The regressions take the following form:

\footnotetext{
${ }^{15}$ We thank Mike Cliff for giving us access to his database of sector matches for the U.S.
} 


$$
\begin{aligned}
\text { underpricing }_{i}= & \alpha+\beta_{1} \operatorname{lnProceeds}_{i}+\beta_{2} \text { Tech }_{i}+\beta_{3} \text { VCbacked }_{i}+\beta_{4} \text { Pr }_{\text {ivatisation }} \\
& +\beta_{5} \text { MultipleBookrunners }_{i}+\beta_{6} \text { Europe }_{i}+\beta_{7} \text { Allstar*region }_{i} \\
& +\left(\sum_{j=1999}^{2007} \beta_{j} \text { Year }_{j}\right)_{i}+\left(\sum_{k} \beta_{k} \text { Country }_{k}\right)_{i}+\varepsilon_{i}
\end{aligned}
$$

Underpricing is calculated as the return on a stock bought at the IPO and sold at the end of the 5th trading day, and is adjusted for market movements using the S\&P 500 Index for U.S. offerings and the applicable local index for European offerings. Other variables are as defined earlier, with the exception of the Europe dummy, which picks up whether underpricing differs between the U.S. and Europe. When we include the All-Star variable we allow for possible differential effects in Europe and the U.S. ${ }^{16}$

The results are in Table 5. Regression (1) reports the results on the whole sample. We find that high-tech and VC backed IPOs are both associated with greater levels of underpricing, and that having multiple bookrunners modestly reduces underpricing. This is broadly comparable with the findings of $\mathrm{Hu}$ and Ritter (2007) who also find weak evidence suggesting that more bookrunners are associated with lower underpricing. We also include year dummies, which, as expected, are significant in 1999 and 2000. The main variable of interest for our purposes is the Europe dummy, which shows that, on average, underpricing of European IPOs is around 9 percentage points lower than in the U.S. This is consistent with the evidence reported in Table 1, and confirms that more accurate pricing does not implicitly offset the higher fees for U.S. IPOs. It is less consistent with research on an earlier period by Ljungqvist, Jenkinson and Wilhelm (2003) who found that U.S. underwriters underprice IPOs by less than other underwriters. As the same banks dominate IPO business on both sides of the Atlantic, it seems unlikely that the nationality of underwriters can explain these underpricing differences, and when we included a control for the presence of a U.S. underwriter it had no economic or statistical significance.

As a robustness check on this result, regression (2) excludes the top and bottom 1\% of the distribution in terms of underpricing, as it is well known that some extra-ordinary under- (and

\footnotetext{
${ }^{16}$ We also checked whether regional interaction effects were significant for the other controls, but found only marginal effects. In the Internet Appendix we report separate underpricing regressions for the U.S. and Europe.
} 
over-) pricing can occur in IPOs. The results are affected little by excluding these extreme observations, although the differential between U.S. and European underpricing falls to $7 \%$ (reflecting the fact that most of the extreme cases of underpricing occurred in the U.S. during the internet bubble).

Finally, we investigate whether underpricing is influenced by the existence of an All-Star analyst in one or more of the bookrunners. As noted earlier, only three-quarters of the IPOs can be allocated into sectors for which Institutional Investor provides rankings in the relevant years, and so the sample size is therefore smaller for regression (3). In general the results are very similar to those found earlier. Regarding the influence of All-Star analysts on underpricing we find differential effects in the U.S. and Europe. In line with previous research on U.S. IPOs (Cliff and Dennis (2004)) we find that syndicates including All-Star analysts are associated with increased underpricing. This is the first paper to extend the analysis to European IPOs and we find a roughly opposite effect - underpricing is around 6 percentage points lower on average, controlling for other issue characteristics, when an All-Star analyst is part of the syndicate. This may reflect the fact that analyst research can be released to investors prior to the IPO in Europe and so the information production process may be better when the most highly rated analysts are involved.

\section{Conclusions}

In this paper we find that the "7\% solution" is now even more prevalent in the U.S. than when Chen and Ritter (2000) reported. Between 1998 and 2007, 95.4 percent of U.S. IPOs between $\$ 25 \mathrm{~m}$ and $\$ 100 \mathrm{~m}$ had spreads of exactly 7 percent fees. Furthermore, the $7 \%$ solution has spread to U.S. offerings up to $\$ 250 \mathrm{~m}$. In contrast, European IPO spreads are consistently lower and are not clustered at a focal point: we find that there is a " $3 \%$ wedge" between European and U.S. IPOs after controlling for size, issue characteristics, syndicate structure and time or country effects. We estimate that, had U.S. issuers been charged European fees, they would have saved over \$1bn a year in investment banking fees. We find that the fees charged to larger U.S. IPOs have tended to increase in our sample period, while European IPOs have been getting cheaper. 
We also show how the same investment banks charge significantly lower fees for conducting IPOs in Europe than for similar IPOs they underwrite in the U.S. ${ }^{17}$

We have reviewed five possible cost differences between the markets that might explain the disparity in spreads. One of these, the treatment of issue expenses, is justified, but accounts for only a small fraction of the gap. None of the other arguments stands up. Indeed, in reviewing the argument that U.S. indirect costs - in the form of underpricing - should be lower than in Europe to compensate for higher U.S. gross spreads, we actually find the opposite to be the case, so that both direct and indirect issuing costs are greater in the U.S. Two questions are raised by our findings. First, why are European IPO spreads lower at all? Second, why did U.S. spreads rise as European spreads fell?

If the different cost structures in the U.S. and European markets have little explanatory power over the disparity in spreads, a possible explanation may be the different levels of competition in the two markets. The U.S. IPO business is concentrated in fewer hands than in Europe, reflected in a Herfindahl index for U.S. IPOs of twice the European value. This may understate the concentration in Europe for, in individual European markets, "national champions" have high local market shares, often reflecting localized demand. It is difficult for non-German IPO underwriters to penetrate the German savings bank network directly, for example. This national champion effect is reinforced by the tendency of European governments to appoint local banks as bookrunners in privatizations. However, the fact remains that the two major categories of banks - U.S. and European - are evenly matched when competing for sizeable European IPO business, while in the U.S. domestic banks dominate. Table 1 shows that, whereas some $28 \%$ of all U.S. IPOs had a non-U.S. bank as at least one of the bookrunners, around 38\% of European IPOs had at least one U.S. bookrunner. This disparity masks considerable variation by deal size. For IPOs above $\$ 500 \mathrm{~m}$ there is a non-U.S. bookrunner in only a third of U.S. offerings (and $95 \%$ have a U.S. bookrunner), while $80 \%$ of European IPOs in this category have a U.S. bookrunner, around the same percentage that have a European bookrunner. U.S. banks seem to have more of

\footnotetext{
${ }^{17}$ Although not the focus of this paper, we also checked how IPOs in Canada compare. In short, Canadian companies that IPO in the U.S. pay U.S. fees - with a large cluster at 7\%. Companies that IPO in Canada seldom pay fees as high as 7\%, with the majority paying 5-6\%, and with considerable variation within each size band. A proper analysis of Canada is outside the scope of the current paper, but this evidence suggests that the U.S. remains an outlier.
} 
their home market to themselves than European banks, particularly when it comes to large offerings.

A further possible explanation is that, although the European market is becoming more integrated, its starting-point was a series of fragmented markets. When bookbuilding became established in Europe in the late 1990s, it replaced a multitude of IPO techniques, including fixed-price offerings, tenders and auctions. Not only were IPO fees low, often 2-3\% in some markets, but there was no focal point around which spread levels could concentrate, in contrast to the U.S. which was a already a well established, unified market.

Over our sample period both Europe and U.S. witnessed entry as the leading banks increasingly won IPO business in foreign markets. The proportion of foreign bookrunners doubled in each market, to $48 \%$ in Europe and to $38 \%$ in the U.S. Moreover, in both regions IPO volumes fell off after the bumper years of 1998-2000. In the face of this market development European IPO spreads have fallen - most strikingly by $1 \%$ for offerings over $\$ 500 \mathrm{~m}$. In contrast, spreads have tended to increase for larger U.S. IPOs, even though it is here that non-U.S. underwriters have made the greatest inroads into the U.S. market. And the spread of the $7 \%$ fee to larger issues has resulted in 77 percent of all U.S. IPOs during the sample period being charged 7\%. Although non-U.S. entrants competed increasingly for U.S. IPO business during our sample period, they did not do so on fees, but rather joined in the strategic pricing which was already a feature of that market.

We conclude that increasing incidence of $7 \%$ fees for larger issues in U.S. IPO, despite entry by European investment banks and a fall-off in the number of IPOs, is consistent with strategic pricing, and in line with models of collusion elsewhere. For example, the rise in spreads during a period of falling volumes is consistent with the dynamic game equilibrium modeled by Rotemberg and Saloner (1986), according to which implicit collusion is expected when current volumes are relatively low. Since punishments for undercutting are meted out in the future, the present value of future profits is expected to be large relative to profits in the current period from achieving a temporarily large market share, and undercutting is therefore deterred.

We are not alone in questioning the level of U.S. gross spreads. In a recent article in the Financial Times ${ }^{18}$ the CEO of AIG is quoted as wanting to "halve the fees paid to Wall Street

\footnotetext{
18 "Psychology behind high fees for underwriting", The Financial Times, 9 September 2009.
} 
banks to take the insurer's units public", and recounts his frustration that there seems to be no room for negotiation. All the evidence in this paper points towards strategic pricing as the explanation for the clustering and level of fees in the U.S. This paper suggests his objective of halving fees is perfectly reasonable, and the evidence presented should provide support to those U.S. issuers who attempt to negotiate European rates.

\section{References}

Alexander, J.C. (1993), 'The Lawsuit Avoidance Theory of Why Initial Public Offerings are Underpriced', UCLA Law Review 41, 17-73.

Beatty, Randolph P. and Ivo Welch (1996), 'Issuer Expenses and Legal Liability in Initial Public Offerings', Journal of Law and Economics 39, 545-602.

Chen, Hsuan-Chi and Jay R. Ritter (2000), 'The Seven Percent Solution', Journal of Finance 55, $1105-1131$.

Christie, William G. and Paul H. Schultz (1994), 'Why do NASDAQ Market Makers Avoid OddEighth Quotes?', Journal of Finance 49, 1813-1839.

Christie, William G., Jeffrey H. Harris and Paul H. Schultz (1994), 'Why Did NASDAQ Market Makers Stop Avoiding Odd-Eighth Quotes?', Journal of Finance 49, 1841-1860.

Cliff, Michael T., and David J. Denis (2004), 'Do Initial Public Offering Firms Purchase Analyst Coverage with Underpricing?', Journal of Finance 59, 2871-2901.

Corwin, Shane A. and Paul Schultz (2005), 'The Role of IPO Underwriting Syndicates: Pricing, Information Production, and Underwriter Competition', Journal of Finance 60, 443-486.

Davidson, Wallace N., Biao Xie and Weihong Xu (2006), 'IPO Placement Risk and the Number of Co-Managers', The Financial Review 41, 405-418.

Drake, Philip and Michael R. Vetsuypens (1993), 'IPO Underpricing and Insurance Against Legal Liability', Financial Management 22, 64-73.

Hansen, Robert S. (2001), 'Do Investment Banks Compete in IPOs?: The Advent of the "7\% Plus Contract", Journal of Financial Economics 59, 313-346.

Hu, Wendy Y. and Jay R. Ritter (2007), 'Multiple Bookrunners in IPOs', Working Paper, University of Florida. 
Jenkinson, Tim and Howard Jones (2009), ‘Competitive IPOs', European Financial Management $15,733-756$.

Jenkinson, Tim and Alexander P. Ljungqvist (2001), Going Public, $2^{\text {nd }}$ edition, Oxford: Oxford University Press.

Jenkinson, Tim, Alan Morrison and William J. Wilhelm (2006), 'Why are European IPOs so Rarely Priced Outside the Indicative Price Range?', Journal of Financial Economics 80, 185-209.

Ljungqvist, Alexander P., Tim Jenkinson and William J. Wilhelm (2003), 'Global Integration in Primary Equity Markets: The Role of U.S. Banks and U.S. Investors', Review of Financial Studies 16, 63-99.

Loughran, Tim and Jay R. Ritter (2004), 'Why has IPO Underpricing Changed Over Time?', Financial Management 33, 5-37.

Lowry, Michelle and Susan Shu (2002), 'Litigation Risk and IPO Underpricing', Journal of Financial Economics 65, 309-335.

Ritter, Jay R. (2003), 'Differences Between European and American IPO Markets', European Financial Management 9, 421-434.

Rotemberg, Julio and Garth Saloner (1986), 'A Supergame-Theoretic Model of Price Wars during Booms', American Economic Review 76, 390-407.

Torstila, Sami (2001), 'What Determines IPO Gross Spreads in Europe?', European Financial Management 7, 523-541.

Torstila, Sami (2003), 'The Clustering of IPO Gross Spreads: International Evidence', Journal of Financial and Quantitative Analysis 38, 673-694. 


\section{Data Appendix}

The main source of our data on IPOs is SDC Platinum, from which we obtained information on all IPOs on US and European markets over the period 1998-2007. In common with most other analyses, we exclude various categories of IPO from our sample: closed-end funds, SPACs, REITs, unit offerings, and offerings where all tranches contain depositary receipts (e.g. ADR or GDR offerings) are all excluded.

Various filters were then applied to this data. First, we applied a size filter: all IPOs where the market capitalization is less than $\$ 25 \mathrm{~m}$ in 2007 U.S. dollars were excluded. This matches (in real terms) the \$20m cut-off used in Chen and Ritter (2000). Second, SDC Platinum specifies the issue method for IPOs; this field is used as the primary filter. However, SDC Platinum mistakenly includes several of WR Hambrecht's OpenIPO auction offerings in the dataset for the U.S. sample of bookbuilt IPOs; 16 of these IPOs are manually removed. Although auction and fixed price techniques in Europe were almost exclusively confined to small (i.e. proceeds of less than \$25 million) IPOs during the sample period, the issuing method of every French IPO is matched against the dataset as a further check to confirm that all fixed price and auction IPOs had been excluded. ${ }^{19}$ This results in an initial sample of 1943 U.S. and 1756 European IPOs for 19982007.

The primary variables of interest in this study are the gross spread and, to a lesser extent, the underpricing of IPOs. For the U.S. offerings, gross spread data is drawn exclusively from the SDC Platinum database, though this is checked against prospectuses and 14 spread adjustments were made. U.S. pricing data is drawn from the Center for Research in Security Prices (CRSP) database. Excluding offerings where spread or pricing data is unavailable leaves a final sample of 1931 United States IPOs.

Compiling equivalent pricing and, in particular, spread information for European IPOs is far more challenging. There is a disparity in gross spread coverage in the SDC Platinum database between the United States and Europe. For our sample, SDC Platinum reports spread

\footnotetext{
${ }^{19}$ France is unique among European countries in that bookbuilt, auction and fixed price IPOs coexisted for many years during the 1990s. Furthermore, unlike many stock exchanges (including the London Stock Exchange), France's exchanges list issue method and thus allow for this check.
} 
information for $99 \%$ of the U.S. offerings but for only $29 \%$ of the European offerings. The scarcity of spread data is almost certainly a function of regulation: in the U.S., it is a regulatory requirement to disclose the level of underwriting fees prominently whereas in Europe, there is no express requirement to do so. Although the underwriting agreement should contain such information, this is sometimes included in a separate document (which is not always available to the public). Even when underwriting expenses are disclosed in European offerings, they are often combined with other expenses (e.g. listing fees) to give an overall cost of the offering to the issuer, which includes but does not reveal the underwriting commission. ${ }^{20}$ To boost the gross spread coverage for European IPOs we bring in data from Dealogic, another leading source of IPO data. This allows us to increase the coverage from 418 to 925 IPOs. Incorporating the Dealogic database required a hand-check of name data to ensure that the maximum additional information is included. There are 389 cases where SDC and Dealogic data is available; in 317 of these $(81 \%)$ the spread values are identical. The average absolute difference between SDC and Dealogic values for the 72 cases where the values did not match is $0.6 \%$; in these cases Bloomberg, news searches and prospectuses (where available) were all used to reconcile the difference. In the absence of additional information, the SDC value is used.

The dataset of European IPO and aftermarket prices is drawn from Datastream, which is regarded as the standard source for this data. However, Datastream is inconsistent in its reporting of prices. The first price is sometimes the offer price, sometimes the opening price of the first trading day, sometimes the closing price of the first trading day. To address this problem, all instances where the Datastream first price is not equal to the SDC Platinum reported offer price were investigated using Factiva news searches. This required a painstaking search of nearly 400 cases and the appropriate corrections to the pricing data where necessary. Excluding 11 offerings where pricing data is unavailable leaves the final sample of 914 European IPOs. ${ }^{21}$

\footnotetext{
${ }^{20}$ We should also note the complicating factor that most European prospectuses are printed in the language of the country where the primary exchange is located, whereas U.S. prospectuses are all printed in English.

${ }^{21}$ In addition, gross spread values that appeared unusually low in the U.S. or the EU are individually investigated using Bloomberg, news searches and prospectuses, resulting the reclassification of 5 IPOs and the omission of a further 15 IPOs.
} 
Banks are defined as either U.S. or European. In most cases this is straightforward, but in a few case judgments have to be made. In particular, we classify Credit Suisse, UBS and Deutsche Bank as European banks, even though they have acquired or merged with sizeable U.S. banks. Regarding mergers, banks that are acquired are, from that point forward, treated as part of their new parent. For instance, BT Alex Brown is classified as a U.S. bank before its acquisition by Deutsche Bank. For all IPOs after the merger, any references to BT Alex Brown (if they occur) are relabeled as Deutsche Bank.

We also gather information on whether the banks that acted as bookrunners for the IPOs had All-Star Analysts, as determined by Institutional Investor (II). In line with Cliff and Denis (2004), it is necessary to re-categorize some II sectors to match the sector classifications for the IPOs in SDC. The matching for Europe differed from the U.S. matching in two respects. First, European II All-Star sectors sometimes differed from the U.S. sectors, with European sectors generally being broader (e.g. there were five separate All-Star bank sectors for the U.S. but only one in Europe), so we ran separate matching exercises for the U.S. and Europe. Second, between 1997 and 1999, II produced separate U.K. and Continental European All-Star rankings, whereas from 2000 it published a single set of pan-European rankings. For European IPOs from 1998 to 2000 we therefore matched each deal with the relevant UK or European II sector, while from 2001 onwards we used pan-European II sectors. However, in both the U.S. and Europe, II do not always produce an All-Star ranking for every sector.

We construct an All-Star dummy variable which takes the value of 1 if at least one bookrunner had an analyst placed first, second or third in the IPO in the relevant sector in the II rankings for either the year of, or the year before, the IPO. Runners-up were not counted. In 698 IPOs, II did not produce a ranking for the relevant sector in either the year of the IPO or the previous year. For the remaining 2147 IPOs we identify All-Star analysts among the bookrunners in 664 cases. 


\section{Table 1: Summary statistics for United States and European IPO samples}

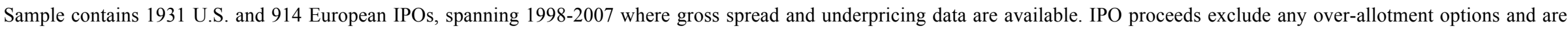

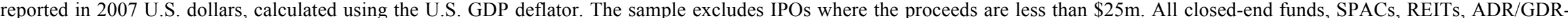

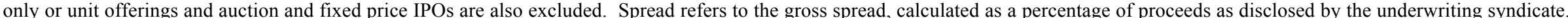

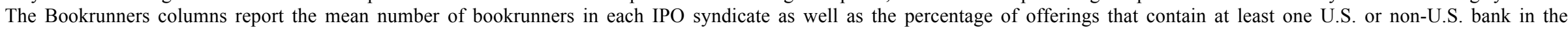

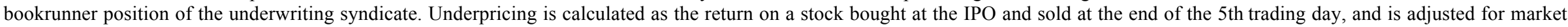
movements using the S\&P 500 Index for U.S. offerings and the applicable local index for European offerings.

\section{Panel A: All Proceeds}

\begin{tabular}{|c|c|c|c|c|c|c|c|c|c|c|c|c|c|c|c|c|}
\hline & \multicolumn{8}{|c|}{ United States } & \multicolumn{8}{|c|}{ Europe } \\
\hline & \multirow[b]{2}{*}{ Count } & \multicolumn{3}{|c|}{ Bookrunners } & \multirow{2}{*}{$\begin{array}{l}\text { Spread, \% } \\
\text { (Mean) }\end{array}$} & \multirow{2}{*}{$\begin{array}{l}\text { Proceeds, } \\
\text { \$m } \\
\text { (Median) }\end{array}$} & \multicolumn{2}{|c|}{ Underpricing } & \multirow{2}{*}{ Count } & \multicolumn{3}{|c|}{ Bookrunners } & \multirow{2}{*}{$\begin{array}{c}\text { Spread, } \\
\% \\
\text { (Mean) }\end{array}$} & \multirow{2}{*}{$\begin{array}{l}\text { Proceeds, } \\
\text { \$m } \\
\text { (Median) }\end{array}$} & \multicolumn{2}{|c|}{ Underpricing $(\%)$} \\
\hline & & Mean & $\%$ US & $\begin{array}{l}\% \text { Non- } \\
\text { US }\end{array}$ & & & Mean & Median & & Mean & $\%$ US & $\begin{array}{l}\% \text { Non- } \\
\text { US }\end{array}$ & & & Mean & Median \\
\hline 1998 & 230 & 1.03 & 80.9 & 19.6 & 6.76 & 65.2 & 21.6 & 9.2 & 106 & 1.42 & 22.6 & 91.5 & 3.98 & 88.6 & 20.0 & 8.0 \\
\hline 1999 & 446 & 1.06 & 81.2 & 21.7 & 6.86 & 80.8 & 73.4 & 39.4 & 142 & 1.50 & 33.8 & 84.5 & 4.09 & 100.9 & 26.3 & 11.4 \\
\hline 2000 & 366 & 1.08 & 74.9 & 28.4 & 6.84 & 95.4 & 58.2 & 26.2 & 203 & 1.41 & 34.5 & 80.8 & 4.24 & 121.0 & 30.0 & 11.8 \\
\hline 2001 & 80 & 1.19 & 77.5 & 32.5 & 6.48 & 143.5 & 13.6 & 8.9 & 44 & 1.75 & 38.6 & 93.2 & 3.45 & 144.2 & 2.8 & 0.0 \\
\hline 2002 & 71 & 1.32 & 80.3 & 33.8 & 6.68 & 132.4 & 6.8 & 8.7 & 18 & 2.11 & 50.0 & 77.8 & 3.29 & 414.5 & 3.9 & 7.9 \\
\hline 2003 & 62 & 1.35 & 82.3 & 38.7 & 6.84 & 139.3 & 12.2 & 11.1 & 15 & 1.80 & 46.7 & 66.7 & 3.30 & 294.9 & 6.9 & 2.7 \\
\hline 2004 & 181 & 1.40 & 85.1 & 30.9 & 6.76 & 98.1 & 12.3 & 6.9 & 59 & 1.86 & 39.0 & 93.2 & 3.18 & 154.8 & 7.3 & 3.7 \\
\hline 2005 & 158 & 1.71 & 90.5 & 30.4 & 6.66 & 128.4 & 11.3 & 6.2 & 88 & 1.67 & 42.0 & 85.2 & 3.37 & 146.1 & 8.8 & 6.7 \\
\hline 2006 & 169 & 1.76 & 89.3 & 34.3 & 6.71 & 118.6 & 12.6 & 6.4 & 115 & 1.69 & 43.5 & 88.7 & 3.37 & 155.7 & 8.4 & 6.7 \\
\hline 2007 & 168 & 1.92 & 92.9 & 38.1 & 6.69 & 110.5 & 14.6 & 8.9 & 124 & 1.92 & 47.6 & 83.1 & 3.20 & 224.2 & 6.2 & 3.5 \\
\hline All Years & 1931 & 1.31 & 82.7 & 28.3 & 6.77 & 95.8 & 36.2 & 13.1 & 914 & 1.62 & 37.6 & 85.4 & 3.71 & 133.1 & 16.5 & 6.5 \\
\hline $\begin{array}{l}\text { All Years ex. } \\
1999-2000\end{array}$ & 1119 & 1.48 & 85.8 & 30.8 & 6.71 & 105.0 & 14.2 & 8.2 & 569 & 1.73 & 39.7 & 87.3 & 3.43 & 152.7 & 9.4 & 5.1 \\
\hline
\end{tabular}


Table 1: Summary statistics for United States and European IPO samples, continued

\begin{tabular}{|c|c|c|c|c|c|c|c|c|c|c|c|c|c|c|c|c|}
\hline \multicolumn{17}{|c|}{ Panel B: $\$ 25 m \leq$ Proceeds $<\$ 100 m$} \\
\hline & \multicolumn{8}{|c|}{ United States } & \multicolumn{8}{|c|}{ Europe } \\
\hline & \multirow{2}{*}{ Count } & \multicolumn{3}{|c|}{ Bookrunners } & \multirow{2}{*}{$\begin{array}{l}\text { Spread, \% } \\
\text { (Mean) }\end{array}$} & \multirow{2}{*}{$\begin{array}{c}\text { Proceeds, } \\
\text { \$m } \\
\text { (Median) }\end{array}$} & \multicolumn{2}{|c|}{ Underpricing } & \multirow{2}{*}{ Count } & \multicolumn{3}{|c|}{ Bookrunners } & \multirow{2}{*}{$\begin{array}{c}\text { Spread, } \\
\% \\
\text { (Mean) }\end{array}$} & \multirow{2}{*}{$\begin{array}{l}\text { Proceeds, } \\
\$ \mathrm{~m} \\
\text { (Median) }\end{array}$} & \multicolumn{2}{|c|}{ Underpricing $(\%)$} \\
\hline & & Mean & $\%$ US & $\begin{array}{c}\text { \% Non- } \\
\text { US }\end{array}$ & & & Mean & Median & & Mean & $\%$ US & $\begin{array}{c}\% \text { Non- } \\
\text { US }\end{array}$ & & & Mean & Median \\
\hline All Years & 1013 & 1.11 & 77.7 & 26.3 & 6.98 & 60.6 & 33.8 & 13.2 & 375 & 1.19 & 12.0 & 92.0 & 4.22 & 52.3 & 22.8 & 7.9 \\
\hline $\begin{array}{l}\text { All Years ex. } \\
1999-2000\end{array}$ & 532 & 1.18 & 79.1 & 26.9 & 6.98 & 59.0 & 14.7 & 7.2 & 213 & 1.19 & 10.8 & 92.5 & 4.14 & 47.9 & 14.4 & 7.7 \\
\hline \multicolumn{17}{|c|}{ Panel C: $\$ 100 \mathrm{~m} \leq$ Proceeds $<\$ 500 \mathrm{~m}$} \\
\hline & \multicolumn{8}{|c|}{ United States } & \multicolumn{8}{|c|}{ Europe } \\
\hline & \multirow{2}{*}{ Count } & \multicolumn{3}{|c|}{ Bookrunners } & \multirow{2}{*}{$\begin{array}{l}\text { Spread, \% } \\
\text { (Mean) }\end{array}$} & \multirow{2}{*}{$\begin{array}{c}\text { Proceeds, } \\
\$ \mathrm{~m} \\
\text { (Median) }\end{array}$} & \multicolumn{2}{|c|}{ Underpricing } & & \multicolumn{3}{|c|}{ Bookrunners } & \multirow{2}{*}{$\begin{array}{c}\text { Spread, } \\
\% \\
\text { (Mean) }\end{array}$} & \multirow{2}{*}{$\begin{array}{c}\text { Proceeds, } \\
\$ \mathrm{~m} \\
\text { (Median) }\end{array}$} & \multicolumn{2}{|c|}{ Underpricing $(\%)$} \\
\hline & & Mean & $\%$ US & $\begin{array}{c}\% \text { Non- } \\
\text { US } \\
\end{array}$ & & & Mean & Median & Count & Mean & $\%$ US & $\begin{array}{c}\% \text { Non- } \\
\text { US }\end{array}$ & & & Mean & Median \\
\hline All Years & 790 & 1.43 & 87.0 & 30.1 & 6.76 & 162.6 & 43.2 & 14.3 & 356 & 1.61 & 43.0 & 80.1 & 3.76 & 201.3 & 13.4 & 4.9 \\
\hline $\begin{array}{l}\text { All Years ex. } \\
1999-2000\end{array}$ & 497 & 1.62 & 90.9 & 33.4 & 6.70 & 171.2 & 14.6 & 9.4 & 228 & 1.71 & 44.4 & 84.2 & 3.34 & 206.6 & 6.6 & 3.3 \\
\hline \multicolumn{17}{|c|}{ Panel D: Proceeds $\geq \$ 500 \mathrm{~m}$} \\
\hline & \multicolumn{8}{|c|}{ United States } & \multicolumn{8}{|c|}{ Europe } \\
\hline & \multirow{2}{*}{ Count } & \multicolumn{3}{|c|}{ Bookrunners } & \multirow{2}{*}{$\begin{array}{l}\text { Spread, \% } \\
\text { (Mean) }\end{array}$} & \multirow{2}{*}{$\begin{array}{c}\text { Proceeds, } \\
\$ \mathrm{~m} \\
\text { (Median) }\end{array}$} & Under & ricing & & & okrunn & & Spread, & Proceeds, & Underpr & $\operatorname{cing}(\%)$ \\
\hline & & Mean & $\%$ US & $\begin{array}{c}\text { \% Non- } \\
\text { US } \\
\end{array}$ & & & Mean & Median & Count & Mean & $\%$ US & $\begin{array}{c}\% \text { Non- } \\
\text { US }\end{array}$ & $\begin{array}{c}\% \\
\text { (Mean) }\end{array}$ & $\begin{array}{c}\$ \mathrm{~m} \\
\text { (Median) }\end{array}$ & Mean & Median \\
\hline All Years & 128 & 2.13 & 95.3 & 32.8 & 5.12 & 849.6 & 11.9 & 8.1 & 183 & 2.53 & 80.0 & 82.5 & 2.60 & 1073.3 & 9.8 & 6.6 \\
\hline $\begin{array}{l}\text { All Years ex. } \\
1999-2000\end{array}$ & 90 & 2.47 & 96.7 & 40.0 & 5.16 & 802.6 & 8.9 & 6.1 & 128 & 2.65 & 81.3 & 84.4 & 2.39 & 1062.7 & 6.1 & 5.1 \\
\hline
\end{tabular}




\section{Table 2: Top Ten Bookrunners by Proceeds for United States and European IPO samples}

See the legend to Table 1 for description of the sample and variables. In this table we sum the total proceeds according to the bookrunner(s) for U.S. and European IPOs. Where there are multiple bookrunners we divide the proceeds equally between the bookrunners. For the purposes of this table we include the deals transacted by bookrunners that were acquired during the sample period into the total for the parent investment bank in the relevant market (e.g. Citigroup includes Salomon Smith Barney and Salomon Brothers). The reported mean spread is the simple (unweighted) average across all the IPOs conducted by each investment bank in each region.

\begin{tabular}{|c|c|c|c|c|c|c|c|c|}
\hline \multirow[b]{2}{*}{ Rank } & \multicolumn{4}{|c|}{ United States } & \multicolumn{4}{|c|}{ Europe } \\
\hline & Bookrunner & $\begin{array}{c}\text { Total } \\
\text { Proceeds } \\
(\$ \mathrm{~m}) \\
\end{array}$ & $\begin{array}{l}\text { Percentage of U.S. } \\
\text { IPO Proceeds } \\
\text { (\$412 billion) } \\
\end{array}$ & $\begin{array}{c}\text { Spread, \% } \\
\text { (Mean) }\end{array}$ & Bookrunner & $\begin{array}{c}\text { Total } \\
\text { Proceeds } \\
(\$ \mathrm{~m}) \\
\end{array}$ & $\begin{array}{l}\text { Percentage of European } \\
\text { IPO Proceeds } \\
\text { (\$417 billion) } \\
\end{array}$ & $\begin{array}{c}\text { Spread, \% } \\
\text { (Mean) }\end{array}$ \\
\hline 1 & Goldman Sachs & 78,139 & 19.0 & 6.45 & Goldman Sachs & 41,568 & 10.0 & 3.50 \\
\hline 2 & Morgan Stanley & 71,106 & 17.2 & 6.45 & Merrill Lynch & 40,838 & 9.8 & 2.81 \\
\hline 3 & Merrill Lynch & 44,875 & 10.9 & 6.52 & Morgan Stanley & 38,807 & 9.3 & 3.48 \\
\hline 4 & Citigroup & 41,354 & 10.0 & 6.42 & UBS & 37,332 & 8.9 & 3.08 \\
\hline 5 & Credit Suisse & 41,115 & 10.0 & 6.63 & Credit Suisse & 30,360 & 7.3 & 3.65 \\
\hline 6 & Lehman Brothers & 25,686 & 6.2 & 6.61 & Deutsche Bank & 26,778 & 6.4 & 3.70 \\
\hline 7 & JP Morgan & 18,245 & 4.4 & 6.48 & Citigroup & 18,167 & 4.4 & 3.30 \\
\hline 8 & Deutsche Bank & 11,523 & 2.8 & 6.79 & JP Morgan & 17,809 & 4.3 & 2.87 \\
\hline 9 & UBS & 11,362 & 2.8 & 6.69 & Mediobanca & 15,300 & 3.7 & 3.42 \\
\hline 10 & DLJ & 9,496 & 2.3 & 6.83 & ABN AMRO & 10,729 & 2.6 & 3.26 \\
\hline
\end{tabular}




\section{Table 3: Determinants of Gross Spreads in the United States and Europe}

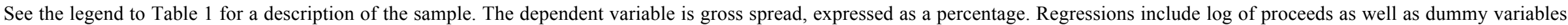

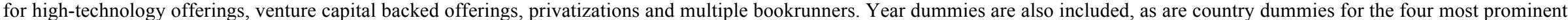

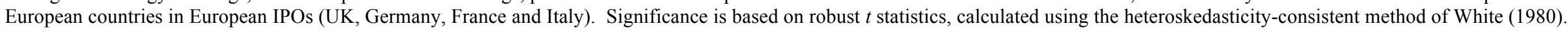

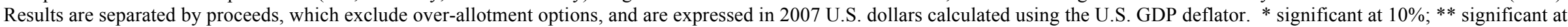
$5 \% ; * * *$ significant at $1 \%$

\begin{tabular}{|c|c|c|c|c|c|c|c|c|c|}
\hline & & \multicolumn{4}{|c|}{ United States } & \multicolumn{4}{|c|}{ Europe } \\
\hline & & $\begin{array}{l}\geq \$ 25 \mathrm{~m} \\
<\$ 100 \mathrm{~m}\end{array}$ & $\begin{array}{l}\geq \$ 100 \mathrm{~m} \\
<\$ 500 \mathrm{~m}\end{array}$ & $\geq \$ 500 \mathrm{~m}$ & ALL & $\begin{array}{l}\geq \$ 25 \mathrm{~m} \\
<\$ 100 \mathrm{~m}\end{array}$ & $\begin{array}{l}\geq \$ 100 \mathrm{~m} \\
<\$ 500 \mathrm{~m}\end{array}$ & $\geq \$ 500 \mathrm{~m}$ & ALL \\
\hline \multirow{5}{*}{$\begin{array}{l}\text { Control } \\
\text { Variables }\end{array}$} & Ln (Proceeds) & -0.04 & $-0.52 * * *$ & $-1.05 * * *$ & $-0.50 * * *$ & -0.03 & $-0.54 * * *$ & $-0.38 * * *$ & $-0.33 * * *$ \\
\hline & Tech & 0.01 & $0.06 * *$ & 0.01 & 0.02 & $0.23 *$ & $0.28 * *$ & 0.03 & $0.23 * * *$ \\
\hline & VC backed & $0.05 * * *$ & $0.10 * * *$ & 0.21 & $0.08 * * *$ & -0.29 & 0.02 & -0.25 & 0.09 \\
\hline & Privatization & - & - & - & - & - & $-0.83 * * *$ & $-0.94 * * *$ & $-0.98 * * *$ \\
\hline & Multiple bookrunners & 0.02 & 0.01 & $-0.27 * *$ & 0.03 & -0.14 & $-0.43 * * *$ & -0.10 & $-0.33 * * *$ \\
\hline \multirow{9}{*}{$\begin{array}{l}\text { Year } \\
\text { Dummies }\end{array}$} & 1999 & 0.01 & $0.18 * * *$ & -0.05 & $0.13 * * *$ & -0.12 & $0.35 *$ & -0.21 & 0.08 \\
\hline & 2000 & -0.01 & $0.22 * * *$ & 0.32 & $0.18 * * *$ & 0.11 & $0.48 * *$ & 0.12 & 0.21 \\
\hline & 2001 & -0.10 & $0.19 * * *$ & 0.30 & 0.09 & 0.14 & -0.08 & $-0.77 * * *$ & $-0.24^{*}$ \\
\hline & 2002 & -0.00 & $0.33 * * *$ & 0.37 & $0.24 * * *$ & 0.73 & -0.09 & $-0.63^{*}$ & -0.05 \\
\hline & 2003 & 0.01 & $0.33 * * *$ & $0.57 * *$ & $0.34 * * *$ & -0.15 & -0.04 & $-0.54^{*}$ & -0.11 \\
\hline & 2004 & -0.04 & $0.21 * * *$ & 0.21 & $0.12 * * *$ & $0.64 * *$ & $-0.72 * * *$ & $-1.32 * * *$ & $-0.55 * * *$ \\
\hline & 2005 & 0.00 & $0.14 * *$ & 0.10 & $0.14 * * *$ & $0.87 * * *$ & $-0.78 * * *$ & $-1.16^{* * *}$ & $-0.37 * *$ \\
\hline & 2006 & 0.02 & $0.15^{* *}$ & 0.24 & $0.16^{* * *}$ & $0.54^{*}$ & $-0.51 * * *$ & $-0.98 * * *$ & $-0.38 * * *$ \\
\hline & 2007 & -0.01 & $0.14 * *$ & 0.22 & $0.14 * * *$ & 0.34 & $-0.53 * * *$ & $-1.01 * * *$ & $-0.41 * * *$ \\
\hline \multirow{5}{*}{$\begin{array}{l}\text { Country } \\
\text { Dummies }\end{array}$} & UK & - & - & - & - & $-0.74 * * *$ & $0.25^{*}$ & 0.31 & -0.05 \\
\hline & Germany & - & - & - & - & $0.91 * * *$ & $0.42 * *$ & $0.40 * *$ & $0.62 * * *$ \\
\hline & France & - & - & - & - & $1.06 * *$ & 0.08 & 0.14 & $0.31 *$ \\
\hline & Italy & - & - & - & - & 0.13 & 0.14 & 0.09 & $0.19 *$ \\
\hline & Constant & $7.12 * * *$ & $9.24 * * *$ & $12.40 * * *$ & $8.92 * * *$ & $4.08 * * *$ & $6.95 * * *$ & $6.10 * * *$ & $5.48 * * *$ \\
\hline \multicolumn{2}{|c|}{$R^{2}$ adjusted } & 0.03 & 0.37 & 0.60 & 0.58 & 0.20 & 0.34 & 0.34 & 0.35 \\
\hline \multicolumn{2}{|c|}{ Observations } & 1013 & 790 & 128 & 1931 & 375 & 356 & 183 & 914 \\
\hline
\end{tabular}




\section{Table 4: U.S. IPO Gross Spreads Adjusted for Underwriters' Legal Expenses}

See the legend to Table 1 for a description of the sample. Typical underwriters' legal expenses represent average values drawn from legal and investment banking sources. Unweighted average spreads are from Table 1. Weighted average spreads use the proceeds of each IPO as weights. For the U.S. IPOs, the Adjusted weighted average U.S. gross spread is calculated by subtracting the typical underwriters' legal expenses from total $\$$ fees (spread x proceeds), and then using proceeds as weights. In Europe the underwriters sometimes bear part of their own legal expenses out of the gross spread (see footnote 9) but this is not reflected in the table.

\begin{tabular}{|c|c|c|c|c|c|c|}
\hline IPO size & $\begin{array}{c}\text { Typical underwriter } \\
\text { legal expenses for } \\
\text { U.S. IPOs }\end{array}$ & $\begin{array}{c}\text { Unweighted } \\
\text { average U.S. spread } \\
(\%)\end{array}$ & $\begin{array}{c}\text { Weighted average } \\
\text { U.S. gross spread } \\
(\%)\end{array}$ & $\begin{array}{c}\text { Adjusted weighted } \\
\text { average U.S. spread } \\
(\%)\end{array}$ & $\begin{array}{c}\text { Unweighted average } \\
\text { European spread } \\
(\%)\end{array}$ & $\begin{array}{c}\text { Weighted average } \\
\text { European spread } \\
(\%)\end{array}$ \\
\hline $\begin{array}{c}\geq \$ 25< \\
100 \mathrm{~m}\end{array}$ & $\$ 250,000$ & 6.98 & 6.98 & 6.58 & 4.22 & 4.23 \\
\hline $\begin{array}{c}\geq \$ 100< \\
500 \mathrm{~m}\end{array}$ & $\$ 500,000$ & 6.76 & 6.63 & 6.37 & 3.76 & 3.57 \\
\hline$\geq \$ 500 \mathrm{~m}$ & $\$ 1,000,000$ & 5.12 & 4.42 & 4.35 & 2.60 & 2.34 \\
\hline All IPOs & & 6.77 & 5.64 & 5.45 & 3.71 & 2.68 \\
\hline
\end{tabular}




\section{Table 5: Determinants of IPO Underpricing}

See the legend to Table 1 for a description of the sample. The dependent variable is Underpricing which is calculated as the return on a stock bought at the IPO and sold at the end of the 5th trading day, and is adjusted for market movements using the S\&P 500 Index for U.S. offerings and the applicable local index for European offerings. Regressions include log of proceeds as well as dummy variables for high-technology offerings, venture capital backed offerings, privatizations, whether the syndicate contains multiple bookrunners, and European offerings. In regression (3) All-Star dummies, calculated separately for U.S. and European IPOs, are included. These takes the value of unity if Institutional Investor (II) ranked analysts associated with one or more of the bookrunners first, second or third in the relevant sector in the relevant region for either the year of, or the year before, the IPO. II do not provide rankings for all sectors for all years, and so the sample size is reduced accordingly when this variable is included. Regression (2) excludes the observations in the top and bottom $1 \%$ of the distribution in terms of underpricing, to check whether the results are influenced by extreme observation. Significance is based on robust $t$ statistics, calculated using the heteroskedasticity-consistent method of White (1980). ${ }^{*}$ significant at $10 \% ; * *$ significant at 5\%; *** significant at $1 \%$.

\begin{tabular}{llccc}
\hline & & Whole sample & $\begin{array}{c}\text { Excluding extreme } \\
\text { obs. }\end{array}$ & $\begin{array}{c}\text { Sample matched } \\
\text { with Analyst sectors }\end{array}$ \\
& & $\mathbf{( 1 )}$ & $\mathbf{( 2 )}$ & $\mathbf{( 3 )}$ \\
\hline \multirow{2}{*}{$\begin{array}{l}\text { Control } \\
\text { Variables }\end{array}$} & Ln (Proceeds) & $0.03^{* *}$ & 0.01 & 0.01 \\
& Tech & $0.19^{* * *}$ & $0.15^{* * *}$ & $0.14^{* * *}$ \\
& VC backed & $0.17^{* * *}$ & $0.12^{* * *}$ & $0.16^{* * *}$ \\
& Privatization & -0.07 & -0.03 & 0.01 \\
\hline \multirow{3}{*}{ Syndicate } & Multiple Bookrunners & $-0.02^{* *}$ & $-0.02^{*}$ & -0.01 \\
& All-Star analyst - US & - & - & $0.08^{* *}$ \\
& All-Star analyst - EU & - & - & $-0.06^{* *}$ \\
\hline Region & Europe & $-0.09^{* * *}$ & $-0.07^{* * *}$ & $-0.04^{*}$ \\
\hline Control & Year Dummies & Yes & Yes & Yes \\
Dummies & Country Dummies & No & No & No \\
\hline \multirow{2}{*}{$R^{2}$ adjusted } & Constant & 0.03 & $0.13^{* * *}$ & -0.01 \\
\hline Observations & & 0.17 & 0.18 & 0.16 \\
\hline
\end{tabular}


Figure 1: Proportion of U.S. IPOs with 7\% Gross Spreads, \$25m-\$100m offerings, 1998-2007

Sample contains 1013 U.S. IPOs with proceeds of $\geq \$ 25 \mathrm{~m}<\$ 100 \mathrm{~m}$, spanning 1998-2007 where gross spread and underpricing data are available. The sample excludes closed-end funds, SPACs, REITs, ADR/GDR-only or unit offerings and auction and fixed price IPOs. Spread refers to the gross spread, calculated as a percentage of proceeds as disclosed by the underwriting syndicate. Proceeds exclude any over-allotment options and are reported in 2007 U.S. dollars, calculated using the U.S. GDP deflator.

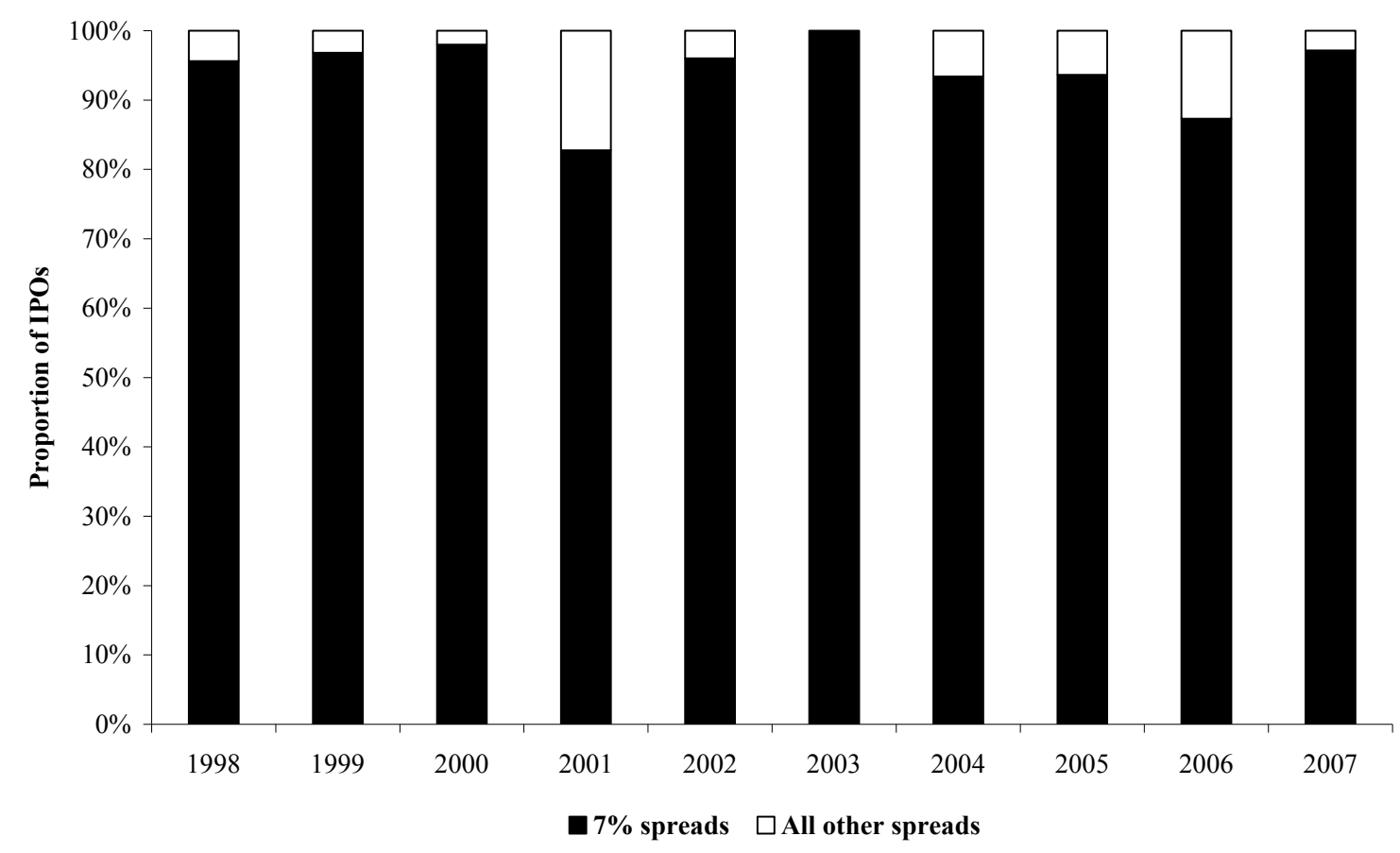


Figure 2: United States vs. European Gross Spreads, \$25m-\$100m offerings,

1998-2007

Sample contains 1013 U.S. and 375 European IPOs with proceeds of $\geq \$ 25 \mathrm{~m}<\$ 100 \mathrm{~m}$, spanning 1998-2007 where gross spread and underpricing data are available. The sample excludes closed-end funds, SPACs, REITs, ADR/GDR-only or unit offerings and auction and fixed price IPOs. Spread refers to the gross spread, calculated as a percentage of proceeds as disclosed by the underwriting syndicate. Proceeds exclude any over-allotment options and are reported in 2007 U.S. dollars, calculated using the U.S. GDP deflator.

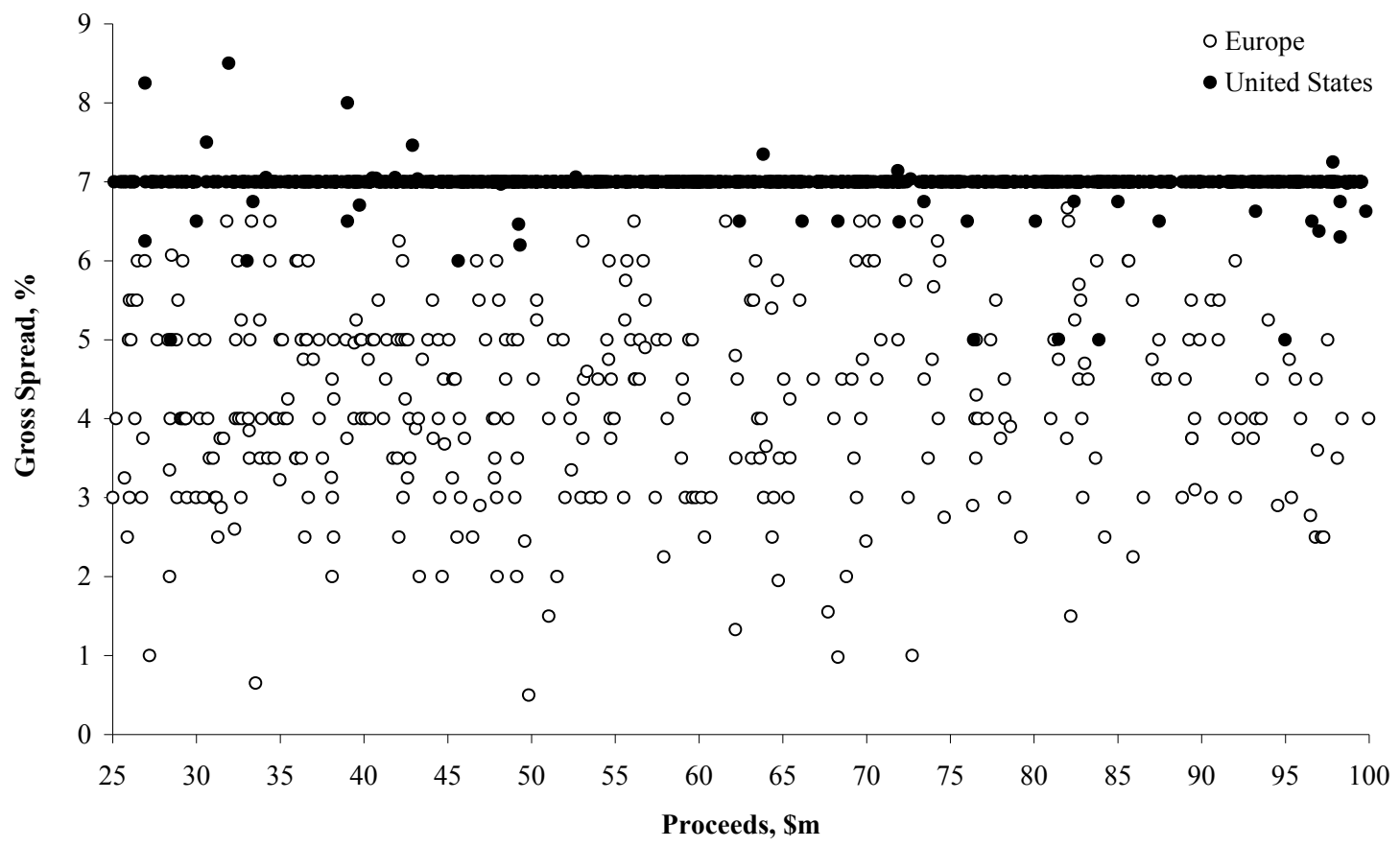


Figure 3: Gross Spreads, 1998-2007

Sample contains 1931 U.S. (Panel A) and 914 European (Panel B) IPOs, spanning 1998-2007 where gross spread and underpricing data are available. The sample excludes closed-end funds, SPACs, REITs, ADR/GDR-only or unit offerings and auction and fixed price IPOs. Spread refers to the gross spread, calculated as a percentage of proceeds as disclosed by the underwriting syndicate. Proceeds exclude any over-allotment options and are reported in 2007 U.S. dollars, calculated using the U.S. GDP deflator.

\section{Panel A: United States}

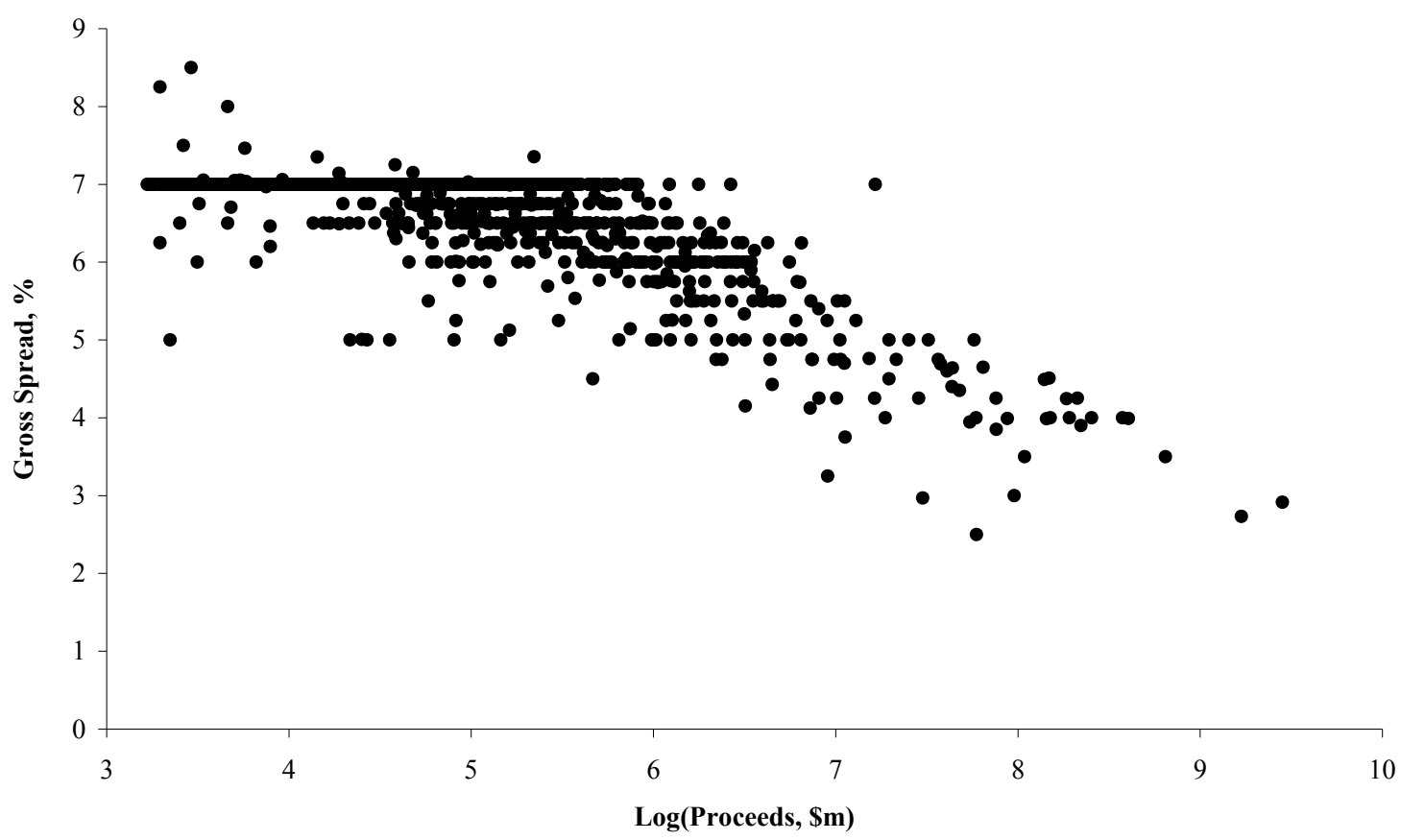

Panel B: Europe

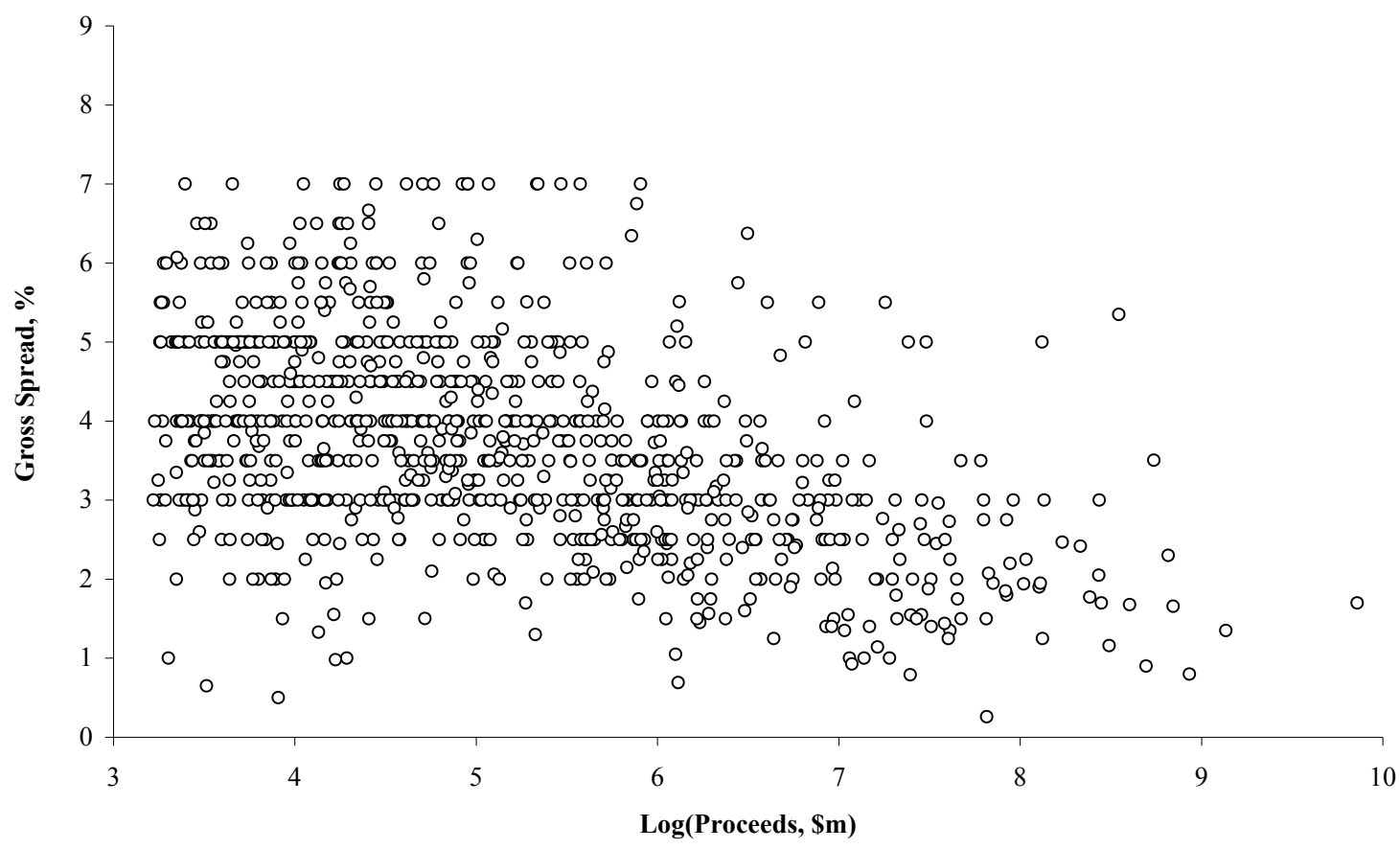

